Essay

\title{
From Triple Win to Triple Sin: How a Problematic Future Discourse Is Shaping the Way People Age with Technology
}

\author{
Louis Neven ${ }^{1, *}$ and Alexander Peine ${ }^{2}$ \\ 1 Active Ageing Research Group, Avans University of Applied Sciences, 4800 RA Breda, The Netherlands \\ 2 Copernicus Institute of Sustainable Development, Utrecht University, 3512 JE Utrecht, The Netherlands; \\ a.peine@uu.nl \\ * Correspondence: lbm.neven@avans.nl; Tel.: +31-88-525-8277
}

Received: 28 May 2017; Accepted: 29 August 2017; Published: 15 September 2017

\begin{abstract}
This essay provides a critical analysis of the ageing-and-innovation discourse. The ageing-and-innovation discourse is a key rhetorical structure that legitimizes very large investments in technologies for older people. In this discourse, ageing is positioned as an imminent crisis that will affect whole societies, both socially and economically. Investing in technological solutions is, in turn, positioned as a solution that generates benefits on a societal, economical and individual level. This discourse is used to legitimize investment, rally support and reduce uncertainty. We contend that there are three problems with the ageing-and-innovation discourse. First, it legitimizes investment in every technology for older people and thus provides no means of discriminating between useful and non-useful technologies. Second, this discourse presupposes a very negative view of ageing that jars with the positive view of ageing that many older people have, which, in turn, leads to problems with acceptance of these technologies. Third, the ageing-and-innovation discourse creates a moral high ground that makes it hard for opponents to disagree with this discourse. The ageing-and-innovation discourse is a successful rhetorical device, but it ultimately hinders the development of suitable technologies that fit in with the lives of older people and thus needs to be reconsidered by scientists, policy makers and industry.
\end{abstract}

Keywords: ageing; innovation; rhetoric

\section{Introduction}

Ageing and the future are intimately related. When we talk about ageing on a personal level, we often envisage how we will live in years to come. When you are a child or teenager, you think about the great things to come and the things you will be allowed to do, such as driving, voting or drinking. As you progress through life, ageing may still be related to great future plans-for instance, what to do when you are retired and you finally get to do what you always wanted. Or, the bitter-sweet, what plans to make in the present to anticipate the potential of bodily decline that may come with ageing at some point and to make your life as comfortable and inspiring as possible till the end.

On a societal level, the relation between ageing and the future is also intimate. In contrast to the personal perspective, the way in which the relationship between ageing and the future is discussed on a societal level has markedly little to do with nice plans. Instead, in aged-care and innovation policy, the relation between demographic ageing and the future is widely discussed as inherently problematic, requiring dedicated actions.

This is an essay about a type of discourse widely enacted by policy makers, scientists and industry practitioners to frame the relationship between ageing, the future and technology, since problematic accounts of ageing are particularly widely used to justify investments into new technologies and 
innovation [1]. Because this discourse is central to this essay, it is useful to illustrate it with an example from a widely-cited article in a robotics journal that presents the structure of the dominant discourse in an unfettered way:

Demographic projections show a rapidly aging population, with the worldwide proportion of people aged over 60 expected to double between 2000 and 2050. As a result, the number of people living with chronic health conditions is increasing and placing demand on healthcare services. There is also an increasing shortage of healthcare professionals, including caregivers for the elderly and registered nurses. Robots have been proposed as one form of assistive device that can help bridge the widening gap between the need and supply of healthcare services. The aged population presents a group who may particularly benefit from healthcare robots. The term 'aging in place' acknowledges the fact that the majority of older people in western cultures are living independently in their own homes, and want to stay there as long as possible, thus avoiding the psychologically traumatic and expensive option of moving to a nursing home or hospital away from familiar surroundings, friends and family. Governments and care funders also favour 'aging in place' to mitigate the expense of the growing number of aged in care. [2] (pp. 319-320)

We have dubbed this way of positioning ageing as a grave problem, and technology as a possible solution, the ageing-and-innovation discourse [3]. In fact, this discourse, or variants of it, has been widely used in innovation policy across developed economies to justify investments into new technological research and piloting, to forge new Public Private Partnerships around technologies for ageing well or to position ageing as an opportunity for economic growth. This essay is not about demonstrating the prevalence of the ageing-and-innovation discourse. This has been done elsewhere by Mort et al. [4], and examples of recent incarnations of the ageing-and-innovation discourse can easily be found across virtually all pertinent innovation policy programmes in Europe. ${ }^{1}$

We use the term discourse in a pragmatic manner, i.e., we are not so much interested in the critical analysis of the actors and means that have shaped the discourse (an interesting topic in its own right, for sure), but in its performative power. That is, we strive to unpack the structure of the discourse itself as a way in which influential players like policy makers, researchers and industry stakeholders talk about the future. As such, the discourse is not neutral but affirms normative role models and values, and lays out an agenda for future actions [8,9]. In this essay, we are interested in these hidden implications of the ageing-and-innovation discourse as a structure 'to be filled in by agency' [9]. We show that this discourse is very attractive from a policy and engineering perspective. We also show that the ageing-and-innovation discourse has profound effects on the way technologies for older people are designed and thereby introduces several problems that ultimately lead to technology that is hard to implement in the everyday lives of older people.

\section{Reflection upon Methodology}

This essay draws together several lines of thinking we have developed over the years and aims to develop them further by taking a dedicated look at the ageing-and-innovation discourse and its implications for ageing. We deliberately position our writing as an essay. By this, we mean that we do not intend to present much in the way of new and systematically gathered empirical material, nor do we intend to develop further ways of analyzing or problematizing the concept of discourse-indeed, the essay form gave us the liberty to boldly stay away from academic discussions around discourse as

1 For a taste, the discourse is part of the strategy of the Active and Assisted Living Joint Program (AAL, see [5]), the aims of the European Innovation Partnership for Active and Healthy Ageing (EIP-AHA, see [6]) and the European Silver Economy Strategy (see [7]). 
concept and ontology. ${ }^{2}$ Rather, we do wish to problematize a specific type of rhetoric that dominates the way ageing and technology are discussed among policy makers, researchers and industry stakeholders. We will do this by bringing in theory and concepts from philosophy and science and technology studies.

In academic terms, our approach comes closest to an auto-ethnography, politically performed [11]. That is, rather than presenting systematically collected data, we present a reflection of our personal experiences over the last five to ten years. During this period, both of us have been deeply involved with a number of European and national activities around innovation policy and design in what is typically called the active and healthy ageing domain. This involvement did include systematic data gathering for other purposes (e.g., [3]) but was mostly driven by our conviction that good social science research should strive for impact outside the academic community. What we single out in this essay is a subtle but equally very dominant way of framing the relation between ageing and innovation, a framing, in fact, that we find so ubiquitous in policy documents, round table discussions, presentations and informal talks with high- to low-level practitioners that we abstain from singling out specific initiatives and projects on this specific occasion. Obviously, however, our involvement with the field has been confined to developed economies, and to those of the European Union, in particular. As a consequence, the elements of the discourse we present are those widely shared by policy makers, scientists and industry representatives in these economies. The point of this essay is to stimulate debate and, hopefully, a richer and more nuanced policy discourse around innovation and ageing.

\section{From Triple Win to Triple Sin}

\subsection{Crisis Account of Ageing}

As we already saw in the citation in the introduction, the ageing-and-innovation discourse typically starts with a statement in which a dire perspective of the future of society is given. This is usually done by means of several supposedly alarming demographic projections and projections of the increase in the cost of care or, for instance, state pensions. Another typical example is the following:

Demographic ageing is one of the most serious challenges Europe is facing. According to recent projections, the number of Europeans aged 65 and over will almost double over the next 50 years $(\ldots$ ). This trend represents a challenge for public authorities, policy makers, businesses and the non-profit sector, especially as it comes at a time of increasing pressure on public budgets, a steady decline in the number of health personnel and growing demands from older people for care products and services. If this demographic transition is not tackled head-on, it will raise considerable concerns for the financial sustainability of health and care systems. Public spending on health already accounts for $7.8 \%$ of GDP in the EU, and by 2060, public expenditure on acute health care and long-term care is expected to increase by $3 \%$ of GDP due to ageing. [12]

The source of this example is relevant; it is a communique of the European Commission to the European Parliament. This type of discourse has been called the 'crisis account of ageing' $[4,13]$. It makes use of a specific kind of future rhetoric. The Dutch philosopher De Wilde [14] distinguishes two kinds of futures. First, 'wenkende toekomsten' - alluring futures that tempt us with beautiful visions of great times ahead. There is a clear message to such future visions: act in the present if you want this beautiful future to come true. Second, there are 'aanstormende toekomsten'- 'hurtling' futures that rush towards us like a speeding locomotive. In this type of rhetoric, an image of a dismal future is conjured up. Compared to the alluring futures, the hurtling futures have a much more pressing message: act now to avoid catastrophe.

2 In fact, we treat discourse as a heuristic and metaphor here, rather than as an analytic concept. For a thorough introduction to the notions of discourse and discourse analysis, see [10]. 
In the different variants of the ageing-and-innovation discourse, the future with ageing is never presented as an alluring future. We could argue that the fact that people are ageing is cause for celebration, as it can be seen as an indicator of the quality of health care and welfare systems. We could also argue that we will all be able to enjoy the presence of our loved ones longer. In essence, the fact that ageing is categorically presented as a 'hurtling' future that is cause for alarm is telling about societal views of ageing. There are, however, good reasons why this negative image of the future is such an attractive image to use. These reasons have little to do with the future but everything with the present.

To understand this in more detail, we can turn to the sociologist of technology and philosopher Harro van Lente and his work on expectations. Van Lente [15] shows that expectations can be used for three purposes: to legitimize intervention, to mobilize support and to reduce uncertainty. With the expectations they raise, images of the future are not neutral descriptions of a time to come, but they perform certain roles in the present. The crisis account of ageing is an example of this. By providing an image of the future in which ageing causes severe social and economic disruption, interventions in the present to prevent this future are legitimized, and support for these interventions is mobilized. The use of demographic and economic projections, in turn, serves to reduce uncertainty about the future. We cannot foresee what the future brings, but surely demography is one of the most reliable forms of future prediction that exists [16], which, by extension, we need to take seriously. By choosing demographic and economic projections that show extreme changes, the reader is convinced that these changes are reliable and certain and require interventions with a sense of urgency. There should be no disagreement; we should act now in unison. Conjuring up an image of a bleak future that hurtles towards us thus serves to convince people in the present that there cannot be any doubt about the future and, consequently, that we need to invest now in interventions to avert this future catastrophe. And the key intervention is often technology.

\subsection{Triple Win: Technology as the Savior}

In deliberate stark contrast to the bleakness of the crisis account of ageing stands technology as the perfect solution to the problem. It is perfect in the sense that, in the rhetoric of the ageing-and-innovation discourse, the technological solutions to the crisis account of ageing result in only winners. Specifically, we can discern three kinds of winners. First, society as a whole wins. Technologies for older people promise benefits like allowing older people to age in place by increasing safety for vulnerable elders or, for instance, by replacing direct human contact in certain elements of care. Benefits like these are subsequently associated with (severe) reductions in the cost of care and/or the cost of social services for older people. The specter of a financial meltdown of care and social services is thus averted by a broad range of technological interventions. Governments are particularly singled out as winners, but health insurers, municipalities and ultimately tax-paying citizens are also on the winning side in the ageing-and-innovation discourse. Second, the older people themselves are seen as winners. Better quality of care and, for instance, the ability to age in place, which is something that all older people apparently want ${ }^{3}$ are benefits that also make the older person, the object of the technological innovation, into a winner (neatly setting aside that such innovations also require a lot of work, passive acceptance and various kinds of costs on the part of older people [18,19]. Finally, the third winner is the economy. By solving social problems with technology, a marketable commodity is produced. Designing, making, selling and maintaining these technologies result in new high-tech jobs and economic growth. Moreover, such technologies can, in theory, also be exported to other countries. Instead of choosing social, human-based solutions to the problems in which demographic ageing is said to result, choosing technological innovation is

3 The home is often represented as the only preferred place to live for older people and as a good place to live. For a critical discussion of this representation in the context of innovation, see [17]. 
accompanied by the promise of economic benefits. We have dubbed this rhetoric of the three winners of gerontechological innovation as the 'triple win' rhetoric [3,20].

Although we do not claim that people have taken this phrase from us, it turned out to be an apt description widely used, especially in the European discourse, as we can see in the example below:

The unprecedented change that is occurring in our society represents as much an opportunity as a challenge. The digital transformation that the world is experiencing in the uptake of digital health technology, solutions and services can drive a triple win for Europe; Better Quality of Care for citizens, more efficient and effective health and care delivery systems, and competitiveness (including new economic opportunities, jobs and investment). This triple opportunity can only be seized if we overcome barriers to scaling up innovation in digital health and connected care and positioning these enablers within a wider, comprehensive and co-ordinated programme of change. [21]

This excerpt comes from the European Blueprint Digital Transformation of Health and Care-a key strategic document outlining a shared vision on how 'innovation enabled by a Digital Single Market can transform Europe's ageing society in the 21st century', driven by pertinent stakeholder networks and endorsed by the European Commission. This most recent incarnation as a centrepiece in a joint stakeholder vision reflects the wide and long-standing use of the triple-win rhetoric in the European discourse, where it has, for instance, helped structure strategies and actions of the European Innovation Partnership on Active and Healthy Ageing (EIP on AHA) from its inception in 2011, where it is positioned as follows:

Why focus on ageing? The European population is ageing rapidly, but living longer does not necessarily mean living a healthier, more active and independent life. The number of Europeans over 65 will double in the next 50 years, and the number of over 80 s will almost triple. Life expectancy will continue to increase, yet unhealthy life years make up around $20 \%$ of a person's life. Active and healthy ageing is a societal challenge shared by all European countries, but also an opportunity. It is a chance for Europe to establish itself as a global leader that is capable of providing innovative solutions. [ ... ] In this context, the EIP on AHA aims to promote healthy and active ageing. [ ... ] It pursues a Triple Win for Europe:-Improving the health and quality of life of Europeans with a focus on older people;-Supporting the long-term sustainability and efficiency of health and social care systems;-Enhancing the competitiveness of EU industry through business and expansion in new markets. [6]

This further demonstrates that the ageing-and-innovation discourse thus has a very clear rhetorical structure. First, a dismal image of the future of ageing societies is painted with the implication that we need to act now to avoid catastrophe. In turn, technology is positioned as the great saviour. The negative, hurtling future is turned completely around into a future where there are only winners-rhetorically simple, but also powerful.

\subsection{Triple Sin? Three Problems with the Ageing-and-Innovation Discourse}

We have shown that the ageing-and-innovation discourse is very popular $[3,4,17,22,23]$. It is used widely in both policy and engineering circles, and it circulates in political documents of the highest level. It is, however, also highly problematic. There are three key problems with the ageing-and-innovation discourse as a structuring element for innovation policy and practice, that may ultimately lead to the development of technologies that are likely to be unfit for use by older people. As such, these three problems can be called the triple sin of the ageing-and-innovation discourse.

The first problem, the first sin, is as simple as it is problematic. We saw that one of the functions of the ageing-and-innovation discourse is to legitimize the investment in technology for older people. The discourse performs this legitimizing role very well for all technologies that fit that bill. Although 
in subsequent technology development there is always some degree of assessment of whether a technology is suitable for older people-often by constructing 'needs' that certain older people are deemed to have, which in itself is problematic [1,24]. The ageing-and-innovation discourse makes every technological development related to ageing legitimate and relevant and thus offers no means to assess the quality of the technology (and indeed hinders this very assessment; see sin number three). This does not increase the chances of developing technologies that fit in well with the lives of older people.

The second sin is strongly related to this fit with the lives of older people. In short, the ageing-and-innovation discourse only works if we view older people in a very negative way. When we look more closely at the ageing-and-innovation discourse, we can see that it relies heavily on drawing relations between ageing and fragility, forgetfulness, illness, weakness, incompetence and so forth. In essence, this discourse thus relies on images of the fourth age [25-28]. Without this negative view of older age, ageing cannot be positioned as a big societal problem. In the ageing-and-innovation discourse, ageing needs to be strongly related to illness, decrepitude and various other negative stereotypes of ageing, otherwise it does not pose a risk to society, and the crisis account of ageing does not hold. Without this negative view of ageing, the rising number of older people would only be a new big group of consumers, in which case, you just end up with an argument for the silver economy [29]. Older people need to be positioned as a problem in order for the ageing-and-innovation discourse to work and for a broad group of stakeholders-not in the least, governments-to get involved. Thus, the ageing-and-innovation discourse cannot do without a negative, fourth-age image of ageing.

However, we also know that this fourth-age image is very problematic with regard to the future implementation of technologies for older people [30]. To explain this, we turn to some classic studies in science and technology studies. Authors like Akrich and Woolgar argued in the early nineties that designers and engineers make images of the prospective user of a new technology and inscribe these images in technologies [31-33]. This leads to a script or scenario for use that constrains and enables certain actions. The user, in turn, interprets this script and either complies with the use scenarios written into the technology, modifies the technology, uses it selectively or rejects the technology altogether [34,35]. A semiotic interpretation of the technology by the user is part of this process, in which technology is or is not appropriated. Users will interpret who the supposed user of a technology is and will compare this to whom they feel they are themselves [36,37]. This is important in the context of the design of technologies for older people.

While the ageing-and-innovation discourse relies heavily on a fourth-age image of older people, most older people do not fit this image. Although there is no clear demarcation between third and fourth age, there can be little discussion about the fact that a big majority of retired people belong to the third-age category. The ageing-and-innovation discourse thus addresses a limited group of older people but even focusing on just fourth-age older people is problematic. We agree with Jones et al.'s [28] definition of the third age as a cultural field and expression of lifestyles, and against this background, we can say that most older people, especially those targeted by digital policies, tend to think of themselves in terms of the third age. The ageing-and-innovation discourse makes use of an imagery of later life that is at odds with the subjective experience of many older citizens. Even if older people can be said to belong to the fourth age by using 'objective' medical categories, or if they might be seen as frail by family members, social workers or doctors, many older people in that group will feel like they are still relatively young and able [38-40].

This has substantial ramifications for the design of technologies for older people. Technologies designed for older people that are based on the images that the ageing-and-innovation discourse provides and indeed requires will very likely lead to technologies that stigmatize older people as old [30]. Older people will identify this as 'technologies for old people', i.e., the fourth-age category. Subsequently they will state things like 'I am not that old', indicating that they do not see themselves as the intended older user of this technology [30]. Alternatively, statements like 'I still go to my checkers club' are made as an indication of an active social life and/or a relatively high level of physical fitness. 
By making such statements, the older people drew a barrier between themselves and what they see as the 'really old', fourth-age-inscribed user of the technology [3,30]. Conversely, technologies that fit in with a third-age image of older people are more likely to be adopted, as they are associated with youthfulness, activity or, for instance, fun [23], as we have shown for the development of e-bikes in the Netherlands [41]. Many older people feel like they are still active and relatively fit people, perhaps despite some bodily problems. They will focus on the positive things in their lives and will not want something in their lives that clearly signifies decrepitude, frailty and old age [30,41,42]. Problems with appropriation of technologies that are based on such negative images are common as a result, even if the technology can make a real contribution to the lives of older people [43]. This leads to an interesting paradox: the ageing-and-innovation discourse is a rhetorical structure that is used with great success to legitimize the development of technologies for older people. However, it achieves this by making use of a very negative image of ageing that will make these technologies very hard to implement in the lives of older people. The rhetoric that makes it successful as a legitimization fatally undermines the acceptability and usefulness of the technologies that are legitimized and made possible, thanks to this rhetoric.

The third problem is that the ageing-and-innovation discourse has clear moral content, which makes it hard to disagree with or argue against this discourse. To understand this, we need to start with the concept of ideograph [14,44]. Ideographs are words like freedom or democracy, which are easily understood as 'good' and are hard to argue against. To be against freedom is tantamount to being an extremist. In line with De Wilde's [14] analysis of 'smart' technologies, we contend that innovation is also an ideograph. Innovation is increasingly seen as something that is good in and of itself and as something that is necessary, both in an economic sense and also to solve societal problems. Innovation is symbolically linked to ideas of progress and the future [14]. We have come to expect a lot from innovation, and the importance of it is frequently discussed in politics, policy circles, academic circles and, for instance, by various stakeholders in the care world. It is no longer necessary to be very persuasive to argue that innovation is important, good or necessary. The rhetorical position of innovation is such that the importance of innovation has become obvious [17,23].

Simultaneously, what innovation exactly means to and delivers for society remains quite vague. Put in another way, ideographs, like innovation (or say freedom or sustainability), have the trait of being interpretatively flexible-what we actually mean when we say innovation can differ for many groups. It can be social innovation or technical innovation. It can be hard-core technology development or the soft social side of, for instance, getting care workers to accept a technology in their everyday care practice. This interpretative flexibility is useful, as it allows different stakeholders to hold different views of what a technology is, what it is for and what it will deliver, but simultaneously also to have a reasonably stable collective idea of what they are jointly working on, as we have shown before for the development of an advanced monitoring system [17].

However, the ageing-and-innovation discourse is not just about innovation for a random group; it is innovation for older people. This carries two meanings with a distinct moral content: first, innovation for older people is positioned as something 'good'. The crisis account of ageing presents ageing as a massive problem that requires our immediate attention, with technological innovation as a saviour that will turn an apocalyptic social future into a future where there are only winners. Innovation thus saves us from a dismal future caused by ageing. That is clearly positioned as a good thing. The second moral meaning of innovation related to ageing is quite opposite of the first one, although it also makes use of stereotypical ideas about ageing. It is the idea that it is good to innovate for frail, vulnerable, lovely, old people. Ageing is not discussed as a menacing social phenomenon, but an individual image is painted of a dear old lady — it is virtually always a lady — who is in need of help and worthy of help. Often, engineers or policy makers do this, referring to what they would want for their mother or grandmother. In a case study on the design and test use of a telecare system, an engineer said, for instance: 'I would actually want my mother or grandmother to use it. Because with such a system ( ... ) we feel like attention is being paid to her, that she can live (at home) safer' 
(for details of this case study, see [3,17]). Technology will thus allow vulnerable old mothers and grandmothers to age well. This is positioned as a second good thing. Technological innovation for older people thus solves a pressing societal issue and, at the same time, aids vulnerable old people who need our help. Who could be against that?

The ageing-and-innovation discourse thus creates a moral high ground. The ageing-andinnovation discourse is positioned by its proponents as if it is 'obviously the right thing to do' from a moral perspective [23], implicitly labelling anyone who disagrees with this discourse as immoral. This makes it hard to disagree with the discourse. It makes it hard to draw attention to the fact that, in the development of these technologies, there is a strong imbalance of power. Mostly experts like doctors, policy makers and engineers decide what is best for older people, which often amounts to design paternalism $[20,45]$. Eventually, older users are involved in innovation processes that ensue; there is no doubt about that, as this is often a requirement for funding, but this involvement often comes too late, as important design decisions have been taken and are already irreversible [46], and, to boot, the input of older test participants is often not taken seriously [30]. The ageing-and-innovation discourse and the innovation projects that are legitimized by it thus have a strong 'technology push' character, but the moral content of the ageing-and-innovation discourse makes it hard to contest this and, importantly, to question the investment of very large sums of money. ${ }^{4}$ This money could have been used in other, perhaps better, ways. Moreover, and perhaps even more importantly, the ageing-and-innovation discourse and its moral content stymie discussion about the way we would like to age with technology, if at all.

One could ask, for instance, why we need this very heavy emphasis on innovation. If we return to the quote from the European Innovation Partnership on Active and Healthy Ageing mentioned above, there does not seem to be a clear link between innovation and the goals of promoting healthy and active ageing and increasing healthy lifespan. Those goals could conceivably also be achieved by social intervention or preventative measures. Technology may well play a role in this, but it need not be innovative new technology. Meaningful socio-technical ensembles that emerge bottom-up can be as good as, or better than, innovative solutions. One area where innovations for older people have attempted to make inroads is in the area of facilitating intergenerational contact. Wordfeud, an app that allows you to play a Scrabble-like game, is being used as an informal care technology to achieve exactly the same [47]. For instance, older adults and their grown-up children are using Wordfeud to have a moment of informal contact. We have observed a case of an older lady who had a son with a very busy job. When she saw that he added a word in the game, she knew he was on a break, and they chatted for a bit; and vice versa, if the son did not see his mother add a word in the morning, he would call to check whether she was ok. Wordfeud was never intended as a care technology; it did not require a government to invest in it, but using it creatively does make it function as a suitable care technology for some people. Moreover, it is a very popular app with older people, and it is thus not stigmatizing. And it is obviously free. The ageing-and-innovation discourse positions innovation as a key solution to the 'problem' of ageing and creates a moral high ground that makes it hard to argue with this discourse. Among other things, this means that social interventions, preventative measures or clever socio-technical ensembles are not likely to be recognized as relevant means to improve the lives of older people. Innovation seems to be the way to go.

\section{Conclusions: The New Futures of Ageing}

The ageing-and-innovation discourse is not harmless. It is a distinct feature of the world of innovation for older people. It is very real, and it has profound effects. It legitimizes investment,

4 Just the Active and Assistive Living (AAL) programme, co-funded by the European Commission, has a budget of 700 million euros. This is just one European programme; there is also funding available from national agencies, both in Europe and elsewhere, and obviously medical and health technology companies are investing in these technologies as well [1]. 
reduces uncertainty and rallies people together in support of these technologies. It provides jobs for researchers and engineers, and it allows governments to state that they are dealing with the ageing society. Ultimately, the ageing-and-innovation discourse is shaping ageing. First, technology and, particularly, innovative technology are normalized as a legitimate and acceptable solution to the problem of ageing. Other solutions are marginalized in turn. Second, there is the materialization of the discourse. The ageing-and-innovation discourse is written into funding programmes. Though designers and engineers have a degree of freedom when they develop technology, they do subscribe to the discourse and 'write' it into their designs. Thus, the discourse and its (in part, ageist) views are materialized into technological artefacts that are offered to older people. Third, the ageing-andinnovation discourse ultimately delivers a neo-liberal view on ageing. Older people are made responsible, by way of the ageing-and-innovation discourse, of taking care of themselves, with technology. They are thus asked to fit the neoliberal mold of a healthy (i.e., not cost-producing) individual. Technology use is made into a nearly moral obligation in a framing that positions ageing as a burden. Innovation, in turn, is the ideal solution from a neoliberal (care) perspective, as it does not require (costly) social intervention but conversely can be commodified and marketed in the silver economy [3,23]. These three ways in which the ageing-and-innovation discourse shapes the future of ageing are not easily recognized. Having a near-axiomatic status in some circles, the ageing-and-innovation discourse leaves little room for debate but paints an ideographic picture that is enticing, seemingly morally just or at least correct, and thus hard to argue against. As such, this discourse profoundly shapes the future of ageing.

The influence of (digital) technology on society over the past decades has been profound. Though nobody can say with certainty what the next decades will bring, the role of technology as an important driver of change seems certain. That is not to say that technology determines the future. Far from it. Older people and technology shape each other, and we need to improve our understanding of this co-shaping. Among other things, this means we need to move beyond the ageing-and-innovation discourse. We need to nuance the crisis account of ageing, criticize the triple-win rhetoric and reject the claim that developing technologies for older people is a morally just and noble cause in and of itself, which puts it above all discussion. Instead, we need to make detailed empirical analyses of the design and use of technologies for older people, how these technologies position older people, whether they fit into the lives of older people, whether they provide them with a positive image, whether they actually benefit older people and how all of this plays out across the diverse spectrum of older people. Such studies would provide the information that can be used to develop technologies for older people in a meaningful way. The ageing-and-innovation discourse actually prevents this. Though it is effective in legitimizing the investment in technologies for older people, if we want to move towards technologies that fit in with and contribute to the lives of older people in a meaningful way, the ageing-and-innovation discourse needs to be superseded.

Acknowledgments: This essay builds on various research projects. The sources of this funding can be found in the relevant references. No specific funding was necessary to finance this essay.

Author Contributions: This essay builds on a line of research that Louis Neven and Alexander Peine have both contributed to substantially over the last years. Both authors contributed during all parts of the study including collection of the data (where applicable) and the analyzing of the data. Louis Neven had the main responsibility for drafting the manuscript and Alexander Peine contributed substantially to this as well. Both contributed equally to the design and planning of the study, the analysis, theoretical interpretations and the writing and revising of the manuscript. Both authors have together critically revised the manuscript.

Conflicts of Interest: The authors declare no conflict of interest. The founding sponsors had no role in the design of the study, in the collection, analyses, or interpretation of data, in the writing of the manuscript and in the decision to publish the results. 


\section{References}

1. Peine, A.; Faulkner, A.; Jæger, B.; Moors, E. Science, technology and the 'grand challenge' of ageing-Understanding the socio-material constitution of later life. Technol. Forecast. Soc. Chang. 2015, 93, 1-9. [CrossRef]

2. Broadbent, E.; Stafford, R.; MacDonald, B. Acceptance of healthcare robots for the older population: Review and future directions. Int. J. Soc. Robot. 2009, 1, 319-330. [CrossRef]

3. Neven, L. Representations of the Old and Ageing in the Design of the New and Emerging: Assessing the Design of Ambient Intelligence Technologies for Older People; University of Twente: Enschede, The Netherlands, 2011.

4. Mort, M.; Roberts, C.; Callen, B. Ageing with telecare: Care or coercion in austerity? Sociol. Health Ill. 2012, 35, 799-812. [CrossRef] [PubMed]

5. Strategy 2014-2020 for the Active and Assistive Living Programme, a European Platform for Ict-Based Solutions Developed With Smes and End-Users to Support Older Adults in Everyday Life. Available online: http:/ / www.aal-europe.eu/wp-content/uploads/2015/11/20151001-AAL-Strategy_Final.pdf (accessed on 12 September 2017).

6. What is the European Innovation Partnership on Active and Healthy Ageing (Eip on Aha)? Available online: https: / / ec.europa.eu/eip/ageing/about-the-partnership_en (accessed on 12 September 2017).

7. The Silver Economy: What is the Silver Economy? Available online: http:/ / www.smartsilvereconomy.eu/ silver-economy (accessed on 12 September 2017).

8. Holstein, M.B.; Minkler, M. Self, society, and the "new gerontology". Gerontologist 2003, 43, 787-796. [CrossRef] [PubMed]

9. Van Lente, H.; Rip, A. Expectations in Technological Developments: An Example of Prospective Structures to be Filled in by Agency. In Getting New Technologies Together-Studies in Making Sociotechnical Order; Disco, C., Meulen, B.V.D., Eds.; Walter de Gruyter: Berlin, Germany; New York, NY, USA, 1998; pp. 203-229.

10. Potter, J. Representing Reality: Discourse, Rhetoric and Social Construction; Sage: London, UK, 1996.

11. Denzin, N.K. Performing [auto] ethnography politically. Rev. Educ. Pedagog. Cult. Stud. 2003, 25, $257-278$. [CrossRef]

12. Taking Forward the Strategic Implementation Plan of the 'European Innovation Partnership on Active and Healthy Ageing' (Com 201283 Final). Available online: http:/ / eur-lex.europa.eu/legal-content/EN/ALL/ ?uri=CELEX:52012DC0083 (accessed on 12 September 2017).

13. Nye, S. Resolving Messy Policy Problems: Handling Conflict in Environmental, Transport, Health and Ageing Policy; Earthscan: London, UK, 2009.

14. De Wilde, R. De Voorspellers, Een Kritiek op de Toekomstindustrie; De Balie: Amsterdam, The Netherlands, 2000.

15. Van Lente, H. Promising Technology: The Dynamics of Expectations in Technological Developments; Eburon: Delft, The Netherlands, 1993.

16. Birg, H. Die Demographische Zeitenwende-Der Bevölkerungsrückgang in Deutschland und Europa; C.H. Beck: München, Germany, 2005.

17. Neven, L. By any means? Questioning the link between gerontechnological innovation and older people's wish to live at home. Technol. Forecast. Soc. Chang. 2015, 93, 32-43. [CrossRef]

18. Milligan, C. There's No Place Like Home: Place and Care in an Ageing Society; Ashgate: Farnham, UK, 2009.

19. Oudshoorn, N. Telecare Technologies and the Transformation of Healthcare; Palgrave Macmillan: Basingstoke, UK, 2011.

20. Joyce, K.; Peine, A.; Neven, L.; Kohlbacher, F. Aging: The socio-material constitution of later life. In The Handbook of Science and Technology Studies, 4th ed.; Felt, U., Fouché, R., Miller, C., Smith-Doerr, L., Eds.; The MIT Press: Cambridge, MA, USA, 2017; pp. 915-942.

21. Blueprint Digital Transformation of Health and Care for the Ageing Society. Available online: http:/ / ec. europa.eu/newsroom/document.cfm?doc_id=40787 (accessed on 13 September 2017).

22. Peine, A.; Neven, L. Social-structural lag revisited. Gerontechnology 2011, 10, 129-139. [CrossRef]

23. Neven, L. Innoveren Voor Actieve Ouderen: Zachte Analyses Als Handreiking Voor Harde En Hardnekkige Problemen; Avans University of Applied Sciences: Breda, The Netherlands, 2015.

24. Hoogma, R.; Schot, J. How Innovative Are Users? A Critique of Learning-by-doing and -Using. In Technology and the Market-Demand, Users and Innovation; Coombs, R., Green, K., Richards, A., Walsh, V., Eds.; Edward Elgar: Cheltenham, UK, 2001; pp. 216-233. 
25. Laslett, P. A Fresh Map of Life: The Emergence of the Third Age; Harvard University Press: Cambridge, MA, USA, 1991.

26. Laslett, P. Necessary Knowledge: Age and Aging in the Societies of the Past. In Ageing in the Past: Demography, Society and Old Age; Kertzer, D., Laslett, P., Eds.; University of California Press: Berkeley, CA, USA, 1995.

27. Laslett, P. Interpreting the demographic changes. Philos. Trans. Biol. Sci. 1997, 352, 1805-1809. [CrossRef] [PubMed]

28. Jones, I.R.; Hyde, M.; Victor, C.R.; Wiggins, R.D.; Gilleard, C.; Higgs, P. Ageing in a Consumer Society: From Passive to Active Consumption in Britain; Policy Press: Bristol, UK, 2008.

29. Kohlbacher, F.; Herstatt, C. (Eds.) The Silver Market Phenomenon: Marketing and Innovation in the Aging Society; Springer: Berlin, Germany, 2011.

30. Neven, L. 'But obviously not for me': Robots, laboratories and the defiant identity of elder test user. Sociol. Health Ill. 2010, 32, 335-347. [CrossRef] [PubMed]

31. Akrich, M. The De-Scription of Technical Objects. In Shaping Technology/Building Society-Studies in Sociotechnical Change; Bijker, W.E., Law, J., Eds.; The MIT Press: Cambridge, MA, USA, 1992; pp. 205-224.

32. Akrich, M. User Representations: Practices, Methods and Sociology. In Managing Technology in Society: The Approach of Constructive Technology Assessment; Rip, A., Misa, T.J., Schot, J., Eds.; Pinter Publishers: London, UK, 1995; pp. 167-184.

33. Woolgar, S. Configuring the User: The Case of Usability Trials. In A Sociology of Monsters: Essays on Power, Technology and Domination; Law, J., Ed.; Routledge: London, UK; New York, NY, USA, 1991; pp. 57-99.

34. Oudshoorn, N.; Pinch, T. Introduction: How Users and Non-Users Matter. In How Users Matter: The Co-Construction of Users and Technologies; Oudshoorn, N., Pinch, T., Eds.; The MIT Press: Baskerville, VA, USA, 2003; pp. 1-25.

35. Wyatt, S. Non-Users Also Matter: The Construction of Users and Non-Users of the Internet. In How Users Matter: The Co-Construction of Users and Technologies; Oudshoorn, N., Pinch, T., Eds.; The MIT Press: Baskerville, VA, USA, 2003; pp. 67-80.

36. Oudshoorn, N. Genderscripts in technnologie Noodlot of uitdaging? Tijdschr. Vrouwenstud. 1996, 17, 350-367.

37. Van Oost, E. Materialized Gender: How Shavers Configure the Users' Feminity and Masculinity. In How Users Matter: The Co-Construction of Users and Technologies; Oudshoorn, N., Pinch, T., Eds.; The MIT Press: Baskerville, VA, USA, 2003; pp. 193-208.

38. Thompson, P. 'I don't feel old': Subjective ageing and the search for meaning in later life. Ageing Soc. 1992, 12, 23-47. [CrossRef]

39. Minichiello, V.; Browne, J.; Kendig, H. Perceptions and consequences of ageism: Views of older people. Ageing Soc. 2000, 20, 253-278. [CrossRef]

40. Hepworth, M. Images of Old Age. In Handbook of Communication and Aging Research; Nussbaum, J., Coupland, J., Eds.; Lawrence Erlbaum Associates Publishers: Mahwah, NJ, USA; London, UK, 2004; pp. 3-29.

41. Peine, A.; van Cooten, V.; Neven, L. Rejuvenating design: Bikes, batteries, and older adopters in the diffusion of e-bikes. Sci. Technol. Hum. Values 2017, 42, 429-459. [CrossRef]

42. Loe, M. Comfort and medical ambivalence in old age. Technol. Forecast. Soc. Chang. 2015, 93, 141-146. [CrossRef]

43. Neven, L.; Leeson, C. Beyond Determinism: Understanding actual use of social robots by older people. In Aging and the Digital Life Course; Prendergast, D., Garattini, C., Eds.; Berghahn: New York, NY, USA, 2015; pp. 84-102.

44. McGee, M. The "ideograph": A link between rhetoric and ideology. Q. J. Speech 1980, 66, 1-16. [CrossRef]

45. Peine, A.; Rollwagen, I.; Neven, L. The rise of the "innosumer"-Rethinking older technology users. Technol. Forecast. Soc. Chang. 2014, 82, 199-214. [CrossRef]

46. Rip, A.; Schot, J. Indentifying Loci for Influencing the Dynamics of Technological Development. In Shaping Technology, Guiding Policy—Concepts, Spaces and Tools; Sörensen, K., Wiliams, R., Eds.; Edward Elgar: Cheltenham, UK, 2002; pp. 155-172.

47. Stigma of Het Nut Van Wordfeud. Available online: http://activeageing.nl/stigma-of-het-nut-vanwordfeud/ (accessed on 12 September 2017).

(C) 2017 by the authors. Licensee MDPI, Basel, Switzerland. This article is an open access article distributed under the terms and conditions of the Creative Commons Attribution (CC BY) license (http:/ / creativecommons.org/licenses/by/4.0/). 